coverage is modeled at around 125 ka (115 ka), due to changes in monsoonal precipitation (see above). By contrast, a more direct response is observed in boreal areas. Here, the temperature effect due to higher (lower) insolation triggers a northward expansion (southward retreat) of the vegetation, leading to large anomalies compared to a control run with present day climatology.

The simulated changes in vegetation are in good agreement with paleoclimatic evidence from proxy records. In particular, the greening of the western part of the Sahara desert at $125 \mathrm{ka}$ is supported by reconstructions from pollen records (van Andel and Tzedakis, 1996). Furthermore, the results are in qualitative agreement with findings from proxy studies evidencing drier vegetation during glacial periods in the African tropics (Jahns et al., 1998). The results for $125 \mathrm{ka}$ agree well with equilibrium simulations produced by the higher resolution model ECHAM4/HOPE-G (EEM
Subproject 2, this issue) and with transient simulations of the lower resolution Climber model, which actually includes more components but of less complexity (EEM Subproject 7, this issue).

So far, the model has simulated strong climate feedbacks, justifying the use of more expensive complex 3-D models. With the inclusion of continental ice sheets via SICOPOLIS, a much stronger response to insolation forcing, necessary for the simulation of glaciation, is expected. Finally, the coupling to HAMOCC will permit the simulation of the long-term response of marine biogeochemistry such as carbon storage/release in the ocean and/or sediment.

\footnotetext{
REFERENCES

Greve, R., 1997: Application of a polythermal threedimensional ice sheet model to the Greenland Ice Sheet: Response to steady-state and transient climate scenarios. Journal of Climate $\mathbf{1 0}$ (5), 901-918.

Jahns, S., Huls, M. and Sarnthein, M., 1998: Vegetation and climate history of west equatorial Africa based on marine pollen record off Liberia (site
}

GIK 16776) covering the last 400,000 years. Rev. Paleobot. Palynol. 102, 277-288.

Maier-Reimer, E., Mikolajewicz, U. and Hasselmann K., 1993: Mean circulation of the Hamburg LSG OGCM and its sensitivity to the thermohaline surface forcing. Journal of Physical Oceanography 23, 731-757.

Roeckner, E., Arpe, K., Bengtsson, L., Brinkop, S., Dömenil, L., Esch, M., Kirk, E., Lunkeit, F., Poneter, M., Rockel, B., Sausen, R., Schlese, U., Schubert, S. and Windelbrand, M., 1992: Simulation of present-day climate with the ECHAM model: impact of the model physics and resolution. Max Planck Institute for Meteorology, Hamburg, Rep. 93.

Sitch, S., Smith, B., Prentice, I.C., Arneth, A., Bondeau, A., Cramer, W., Kaplan, J.O., Levis, S. Lucht, W., Sykes, M.T., Thonicke, K. and Venevsky, S., 2003: Evaluation of ecosystem dynamics, plant geography and terrestrial carbon cycling in the LPJ Dynamic Global Vegetation Model. Global Change Biology 9 (2), 161-185.

Van Andel T.H. and Tzedakis, P.C., 1996: Palaeolithic landscapes of Europe and environs: 150,000-

25,000 years ago: an overview. Quaternary Science Reviews 15, 481-500.

Winguth, A., Archer, D., Maier-Reimer, E., Mikolajewicz, U. and Dupplessy, J.-C., 1999: Sensitivity of the paleonutrient tracer distribution and deep-sea circulation to glacial boundary conditions. Paleoceanography 14, 304-323

\title{
GHOST (Global Holocene Spatial and Temporal Climate Variability): Combination of Paleotemperature Records, Statistics and Modeling
}

\author{
R.R. Schneider ${ }^{5}$, J.-H. KIm ${ }^{1}$, N. Rimbu ${ }^{2}$, S. Lorenz ${ }^{3}$, G. LohmanN ${ }^{2}$, U. Cubasch ${ }^{4}$, J. Pätzold ${ }^{1}$ ANd G. WefeR ${ }^{1}$ \\ ${ }^{1}$ FB5 Geowissenschaften, Allgemeine Geologie \& Meeresgeologie, Universität Bremen, Klagenfurter Straße, 28359 Bremen, Germany \\ ${ }^{2}$ FB5 Geowissenschaften, Erdsystemmodellierung \& Analyse, Universität Bremen, Klagenfurter Straße, 28359 Bremen, Germany \\ ${ }^{3}$ Max-Planck-Institute für Meteorologie, Modelle \& Daten, Bundesstraße 55, 20146 Hamburg, Germany \\ ${ }^{4}$ Institut für Meteorologie, FU Berlin, Carl-Heinrich-Becker Weg 6-10, 12165 Berlin, Germany \\ ${ }^{5}$ Dept. de Géologie et Océanographie, UMR5805-EPOC, CNRS/Univ. de Bordeaux1, 33405 Talence Cedex, France; r.schneider@epoc.u-bordeaux1.fr
}

In the GHOST project, we explore the evolution of Holocene seasurface temperatures (SSTs). Our perspective consists of two baselines: the archiving and statistical evaluation of worldwide distributed existing, reedited, and newly collected marine alkenone-derived paleotemperature records and the use of actual but low-resolution general circulation models with high computational efficiency, designed for long-term paleoclimate studies.

We consider SST records solely based on the alkenone method in order to avoid potential bias due to using different SST proxies (Kim and Schneider, 2004). Our novel modeling strategy uses a technique for transient simulations with state-of-the-art climate mod- els on paleoclimate time scales. By accelerating the very slow time scale of the Earth's orbital parameters within a fully coupled atmosphere-ocean circulation model, we are able to investigate the influence of the slowly varying annual distribution of solar radiation on the climate of the Holocene (Lorenz and Lohmann, 2004).

Statistical analysis of alkenonederived SST records indicates a transition from relatively cold to relatively warm conditions in the tropics from the middle to late Holocene (Rimbu et al., 2004). This tropical warming was accompanied by a SST decrease in the Northeast Atlantic, as well as in the western Mediterranean Sea, and a warming in the eastern Mediterranean Sea and the Northern Red Sea (Fig. 1a and $1 \mathrm{~b}$, Kim et al., 2004). This SST distribution pattern resembles the modern AO/NAO-related SST pattern from this region, suggesting a transition from a more positive to a more negative phase of AO/NAOlike atmospheric circulation from 7 cal. kyr BP to the present. An analogy with the instrumental period suggests that this Holocene SST pattern is due to a decrease (increase) of southwest (northwest) wind strength over the eastern North Atlantic (the northern Red Sea) (Fig. 2c, Rimbu et al., 2003). Model experiments (Lorenz and Lohmann, 2004) confirm the results of statistical analysis of alkenone SST data and show that the phase and amplitude of AO/NAO is controlled by the variation in solar insolation over the tropics 


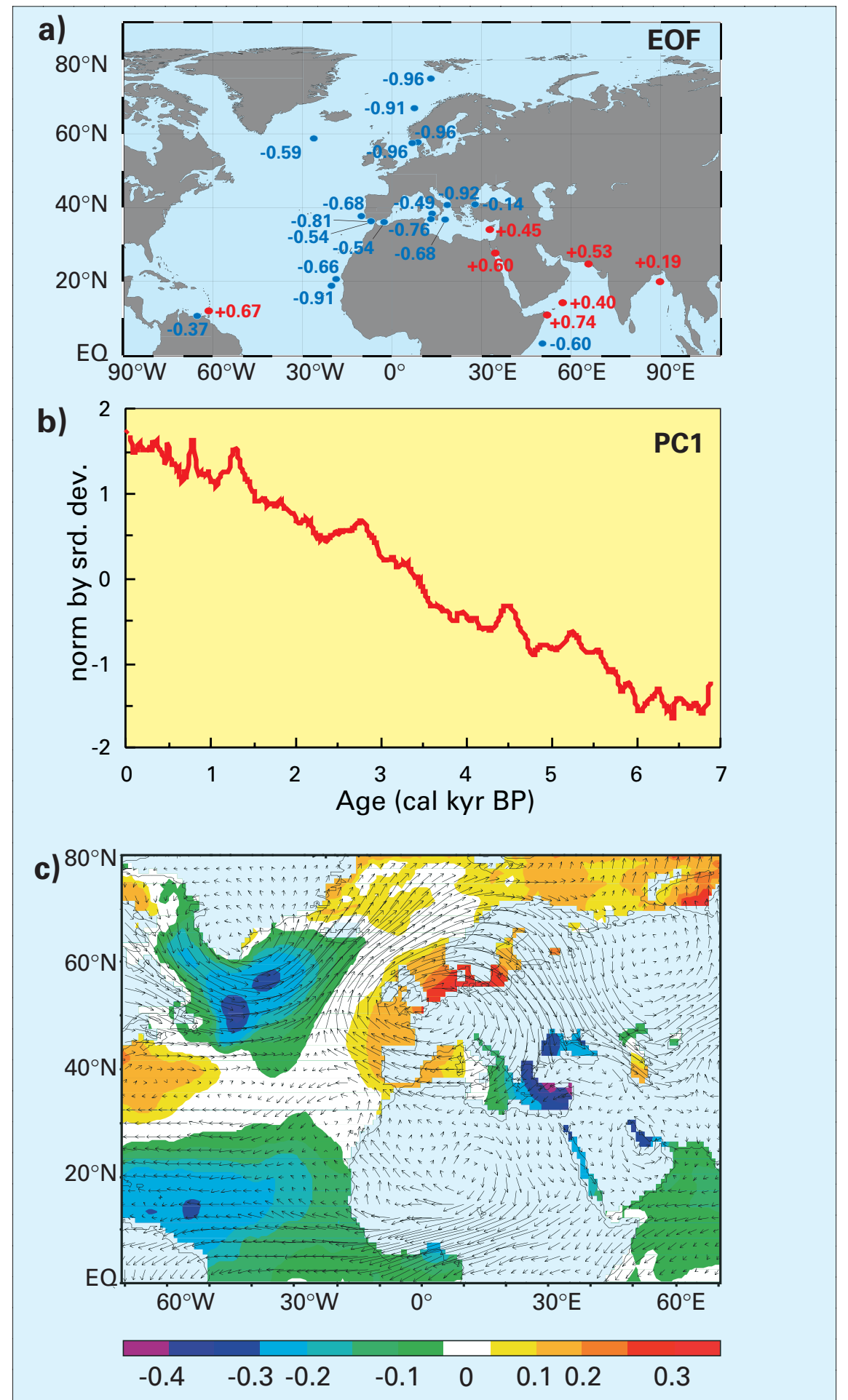

Fig. 1: The first EOF of alkenone-derived SST variations (a) and its corresponding expansion coefficient time series (PC1) (b) (Kim et al., 2004). The values on the EOF map represent the correlation coefficient between PC1 and the smoothed and normalized SST field. (c) Regression map of the SST index based on Holocene SST records, and SST and $850 \mathrm{hPa}$ wind (vector) during the instrumental period (Rimbu et al., 2003), which is an analogous situation for the middle Holocene. Based on the Holocene SST trend pattern, the SST index was defined by subtracting the averaged SST anomalies over the region dominated by a positive Holocene SST linear trend $\left[\left(5^{\circ} \mathrm{N}-20^{\circ} \mathrm{N} ; 70^{\circ} \mathrm{W}-60^{\circ} \mathrm{W}\right)\right.$ and $\left.\left(20^{\circ} \mathrm{N}-40^{\circ} \mathrm{N} ; 20^{\circ} \mathrm{E}-40^{\circ} \mathrm{E}\right)\right]$ from the averaged anomalies over the region dominated by a negative trend $\left[\left(30^{\circ} \mathrm{N}-75^{\circ} \mathrm{N} ; 10^{\circ} \mathrm{W}-20^{\circ} \mathrm{E}\right)\right]$. Units in (c) are ${ }^{\circ} \mathrm{C}$ and $\mathrm{ms}^{-1}$

during the boreal winter season (December/January/February) associated with the Earth's precession cycle (Milankovitch forcing). Further statistical analysis of the alkenone SST data reveals 2.5-kyr and multi-centennial oscillations during the Holocene (Rimbu et al., 2004).

Accordingly, the similarities of alkenone-based and simulated surface temperature trends sug- gest that the insolation forcing had a dominant influence on the surface temperature change during the Holocene, mainly on the northern hemisphere and the tropics. Additional climate modes, e.g., the AO/NAO pattern over Europe can amplify or weaken the significant impact of long-term insolation changes on Holocene climate. We envisage that our approach in collaboration with other DEKLIM-Paleo projects will (1) help to disentangle long-lasting, natural climate trends from anthropogenic perturbations, (2) increase our knowledge about spatial and temporal heterogeneity of natural climate variations under warm climate conditions, (3) allow comparison of Holocene climate change with that of other prominent interglacials (Isotope stages 5 (Eemian) and 11), and (4) provide a basis for the evaluation of the performance of coupled Atmosphere-Ocean General Circulation Models (AOGCM's) in simulating natural climate change well before the instrumental period which may have already been affected by human activities.

\section{RefERENCES}

Kim, J.-H. and Schneider,R.R., 2004: GHOST global database for alkenone-derived Holocene sea-surface temperature records. http: //www.pangaea.de/Projects/GHOST/Holocene

Kim, J.-H., Rimbu, N., Lorenz, S.J., Lohmann, G., Nam, S.I., Schouten, S., Rühlemann, C. and Schneider, R.R., submitted: North Pacific and North Atlantic sea-surface temperature variability during the Holocene, Quat. Sci. Rev.

Lorenz, S.J. and Lohmann, G., in press: Acceleration technique for Milankovitch type forcing in a coupled atmosphere-ocean circulation model: method and application for the Holocene. Climate Dynamics.

Rimbu, N., Lohmann, G., Kim, J.H., Arz, H.W. and Schneider, R.R., 2003: Arctic/North Atlantic Oscillation signature in Holocene sea surface temperature trends as obtained from alkenone data. Geophy. Res. Lett. 30, 1280, doi:10.1029/ 2002GL016570.

Rimbu, N., Lohmann, G., Lorenz, S.J., Kim, J.H. and Schneider, R.R., in press: Holocene climate variability as derived from alkenone sea surface 